\title{
My Work is Yours to Do What I Want
}

\author{
REBEKAH MODRAK
}

Professor in Penny W. Stamps School of Art \& Design, University of Michigan

\begin{abstract}
My Work is Yours to Do What I Want narrates the trajectory of two companies, one of them actual (Best Made Co.), and the second (Re Made Co.), an artwork posing as a company that uses remix to strategically confuse, conflate, and disrupt consumer culture. Re Made appears to be an online company founded by the fictitious character Peter Smith-Buchanan, and selling $\$ 350$ hand-painted plungers. The entire event of Re Made offers an alternate universe-both digital and real — for Best Made Company, which was founded by (the real) Peter Buchanan-Smith, and specializes in $\$ 350$ artisanal axes. Like a cloned twin or digital virus, Re Made and Buchanan-Smith mimic Best Made and Smith-Buchanan. If Best Made posts a decapitated pig's head with an axe in its mouth on social media, Re Made's BBQ pig gnashes a plunger on Instagram. When a New York Times feature refers to the Best Made axe as "manly," a divergent NYTimes article heralds the masculine plunger. Peter Buchanan-Smith declares the axe to be "embedded in men's DNA," and Smith-Buchanan proclaims the plunger an extension of men's bodies. The real Peter Buchanan-Smith emails $R e$ Made's CEO Peter Smith-Buchanan insisting he stop this plunder of reality. Acting as SmithBuchanan's intern, I (the female creator of the artwork) reply. Best Made's lawyers send Re Made's lawyers a 32-page cease-and-desist documenting the paths converging too closely for their liking. Just as the artwork Re Made uses remix via a media-based platform to intentionally confuse "original" content and appropriated material, My Work is Yours to Do What I Want playfully narrates the impulses and parasitic manipulations of all members involved, shifting agency and identity between hosts and parasites.
\end{abstract}

\section{My Work is Yours to Do What I Want}

In 2009, Peter Buchanan-Smith perceived of the need for a better axe. Or maybe the $\$ 200$ of wagyu that he purchased in Manhattan inspired the need for a better axe. One purchase paving the road and setting the standard for the next. It was the height of the Great Recession. Buchanan-Smith closed his design office, laid off his staff, and bought 200 Benjamins-worth of Japanese beef.

Pardon. These two details aren't supposed to be in the same story. In your mind, please separate them. Place the recession detail in the come-back fable. Entrust the wagyu tale to the most unconfident part of your psyche, the one that's reassured and relieved by expensive meats. . . Let's continue. 
Wagyu needs to be grilled on a hot wood fire. Cutting tinder for the wagyu fire with a plastic Home Depot axe is unsatisfying. These two truisms also led to Buchanan-Smith's perception of the need for a better axe and inspired his experimentation in bettering with an eBay-purchased, vintage, wooden axe. In his garage, newly filled with tools and woodworking equipment, he painted the axe's wooden handle. The now colorful axe brought him happiness. He wanted to share this happiness with the world in the form of a collection of axes in striped colors, in the same way that fashion is shared with the world by wealthy people getting exclusive, well-fitting couture and others encountering drip-down mutated versions falling from hangers at H\&M. Best Made Company would be the couture of axes. This axe-sharing-happiness would cost $\$ 300$.

The axe will be "simple and sweet," thought Peter Buchanan-Smith. Or maybe he didn't think that. But later he thought to tell someone else he had thunk it. Two years later, he tried out the words on a New York Times Style reporter, "With the ax, I wanted to do something simple and sweet." Ms. Green writes this down and publishes the quote without asking how an ax is sweet. Sometimes, things so contradictory just have a rightness. Green makes sure to also mention the axe's manliness. In the subliminal reading of the article, "manly" will negate "sweet."

Buchanan-Smith tells Ms. Green the part about the axe being an invitation to share happiness with the world. An invitation to happiness that will grow to be an influential lifestyle brand. Advertising executive Andy Spade agrees.

All of this because finely marbled beef needed to be roasted on a wood fire.

But maybe the wagyu didn't inspire the need for a better axe. Maybe it was the MFA degree in Design from the School of Visual Arts and Buchanan-Smith's thesis lovingly celebrating undervalued objects. Cat's whiskers. Dust. Never-lipped lipsticks. Joy and pleasure in objects under-appreciated or discarded. At Buchanan-Smith's final thesis defense, Professor Skiller joined in with a lofty sermon in praise of dust. The dust-laden rhetoric prompted a hazy realization: had he forgotten to leave payment for his house-cleaner on the dining room table? The thought made him uncomfortable and he shook it away.

Some might say it was Professor Benjamin's absence from the thesis review that paved the way for a better axe. The third faculty member of Buchanan-Smith's thesis committee missed her connection from the 7 train to the 6 . The rest of the committee sighed with relief. Professor Benjamin, practical and forbidding, would have impolitely brought up the Nazi genius for using seductive slogans and propaganda to make fascism seem appealing. Professor Benjamin would have insisted on discussing the dirtiness of dust, which might have seeded prudence in Buchanan-Smith's head so that, on the day of the wagyu feast, that kernel might have inspired a moment of truth where real things have real meanings. Buchanan-Smith and his kernel of conscience would have an internal argument. The joy of profiting by selling upscaled symbols of manual labor to wealthy men would be tarnished. Persuading men that manliness is a lethal, razor-sharp weapon might seem archaic by a few hundred years. Even the wagyu might have seemed excessive.

But Professor Benjamin never got off at Grand Central Station. To her embarrassment, she rode all the way to the Queensboro Plaza where she cut her losses and indulged in a plastic cup of chili-spiced, sliced mango purchased from a Colombian street seller. As a matter of fact, Professors Benjamin and Skiller are imaginary guests in this story, a small and isolated insertion of fiction tainted with more reality than our story of fantastical truth. 
There was no Professor Benjamin to thwart the plans for a better axe, so purchase orders are sent to Maine, where a family company has hand-forged axes for over a hundred years. Their truck, loaded with tools in Smyrna, heads past Duck Pond, and snakes through the spruce forest. By the time it reaches Buchanan-Smith in Manhattan, the tire treads have lost all trace of loamy soil and evergreen needles and are wedged with chewing gum and shards of broken glass.

Dust can be dust and cat whiskers cat whiskers, but axes get the Emerald City treatment. Buchanan-Smith causes them to be sanded, painted, branded, titled, and storied.

We stopped in Emmett to change our city duds for some heavy worsted wool. Snow was coming, we were on horseback and heading into the Payette National Forest with our best buds Nate Bressler and Remington Kendall to hunt elk. An adventure was had, and a series of axes devoted to some of our stops along the way were adorned and emblazoned...

The axe is embarrassed. It blushes under its fresh coat of fern green paint with white and red stripes.

His arms full of bespoke axes, his belly full of wagyu beef, Buchanan-Smith is fortunate to have a community of people who understand axes. Fashion designer Isaac Mizrahi. Senior curator of design at the Museum of Modern Art, Paola Antonelli. Wilco. David Byrne. Philip Glass.

Buchanan-Smith is a cultural prince, a former art director of The New York Times' Op-Ed page, a designer of books and albums for "high-wattage" clients (Ms. Green' words). He blows a long, low blast into his secret whistle and the royal marketeers pad in on velvet slippers.

\section{Shuffle muffle duzzle dines}

Gear Patrol and New York Times.

We are men of brand attraction.

Our magic hides dissatisfaction.

Add phantom memories to the pot.

Make things seem old when they are not.

Arrange men in woods with fire and action

Mention Teddy Roosevelt and Andrew Jackson

Camping chic with enamel vessels,

Make men feel that they are special.

Old Spice stages a historical reenactment of pioneer days without consulting a historian and publicizes the event by parroting the graphics of $\mathrm{J}$ Crew. Add the air of the literary, the voice of a $\mathrm{J}$ Peterman catalog, and the attitude of Alpha Delta. This is the Best Made Co. story.

BEST MADE SOCIAL MEDIA AND WEBSITE - SWEAT. DIRT. WORKERS.

A backdrop of dense bamboo-like grasses. Brazilian sugar cane workers dressed in $\$ 158$ Best Made WorkShirts hold machetes and grin at camera. Three have liver disease from severe dehydration. But they are handsome and rugged and show no signs of illness during the twenty minutes of shooting. 
BEST MADE SOCIAL MEDIA AND WEBSITE - ADVENTURERS .

Somewhere in the Texas Badlands, men. A pilot astride his Air Tractor plane. A photographer standing atop his car, camera rigged on top. He gazes at The Glass Mountain. The leathered face of a cowboy running down a bull. Unsparing, unsentimental.

Scene change. Greenland, 1906. Danish gentleman adventurer. Rides a dogsled across the frozen wastes wearing the coat of a polar bear he killed himself. Amputates his own toes with pliers.

Prospectors who froze to death in the Yukon. A campfire meal of steak and heirloom tomatoes [sprinkle of crumbled feta]. Free-range chicken farmers. Three Best Made employees surround a tree and watch each other strike it, over and over and over and over and over and over. Director note: Compose with strong diagonals and artsy foreground and background. Overcome associations of gang rape and lynching with Bon Appetit flair.

"Painting the handles was a means of giving the axe some life beyond the sinister associations," says Buchanan-Smith. Best Made Co. and its collection of painted American Felling Axes opens with a whack and a flourish in brick and mortar on White Street in Tribeca, New York, and online at bestmadeco.com. The insurance agent reviews the request for liability insurance. His frown lines deepen while looking at a photo of a beanie-wearing man with a hard stare, a saddled horse, and a shiny painted axe. He suggests precautions: kneeling while chopping to reduce risk? Safety goggles? Less alcohol? Buchanan-Smith counters: "Let's attach a few cherished virtues to the axes-courage, compassion, grace, fortitude-as a non-legal, but more emotionally binding measure of built-in liability insurance."

"That will be $\$ 300$ sir," says the sales clerk. Emmett, the American Felling Axe, feels itself lifted up, then settled on a bed of wood wool in a custom-fitted wooden box. "I've been reborn as a taxidermied wolverine," thinks the axe. Searching through the slivered wood, it finds the certificate of authenticity, the papers noting care instructions, and the registration for its name. Soon, the box is re-opened and Emmett, the American Felling Axe, aka Stuffed Skunk Bear, is mounted above the mantel. A man snaps a photo and shares it to Facebook, "Thanks, Best Made! She's a beaut. Freakin awesome." He and his buddies drive the two hours to Lumberland, New York. They pose with Emmett and the other axes in the woods, take selfies against a backdrop of American flags, declare that "the axe is in their DNA," and drink whiskey. 568 miles west, on a campsite in Lapeer, Michigan, men pose with AR-15 pistols modified to mimic rifles, wave American flags, speak of "the guns in their blood," and drink jugs of milk.

In 2013, Peter Smith-Buchanan perceived of the need for a better plunger. He perceived this need without having purchased any wagyu, without having laid off any employees. Upon reflection, he never did perceive of the need for a better plunger. But he had an impulse to hold a "better plunger" in his hands while declaring, in the persuasive voice of Peter Buchanan-Smith:

"This is the oldest tool ... and actually ... the oldest artform known to mankind. This has to be embedded in our DNA. You know, it's wood and a piece of rubber put together, sitting there in this capsule of stored energy. That's what makes it very powerful. You 
put a plunger in someone's hands and they feel empowered. It's a tool that ... in a sense ... builds America."

Smith-Buchanan trusts his instincts. His instincts say to follow Buchanan-Smith's instincts. His existence is limited to the contours of Buchanan-Smith's shadow. He is a puppet figure whose will and being are directed by his unknowing puppeteer. To describe this in a more literary way, he is the monster of Buchanan-Smith's labor in a Frankenstein story. Our $21^{\text {st }}$ century Dr. Frankenstein is recast as an the entrepreneur, smitten with his own ambition and unable to accept moral responsibility for the creation he has brought into the world. But we're moving ahead of ourselves. For now, it is enough to say that Smith-Buchanan is all action, with no thoughts of his own except to relentlessly hitch his plunger to Buchanan-Smith's axe.

Smith-Buchanan looks at the axe empire created by Buchanan-Smith and begins to build his plunger version. He hires a film crew. Buys a plunger at the hardware store. Sands, paints, brands, titles, and stories it as a Re Made American Master Plunger, name of Emmett. He buys an American flag. Puts on a red beanie and his navy sweater. Hangs some hard hats and a red dust pan on the wall of his studio. Pins up photos of Kermit the Frog and Buster Keaton. He copies down Buchanan-Smith's words and, phrase by phrase, speaks them to the camera in his most persuasive voice. "This is the oldest tool ... and actually ... the oldest artform known to mankind...."

The brand video goes online with all the necessary embellishments to create a better plunger company: the collection of upscale plungers, the return policy, the photos of adventurers and men brandishing Master Plungers at their campsite in Plumbland, the "Add to Cart" button, and the social media links. The Cart is temporarily out of service.

Peter Smith-Buchanan sits at his desk in the Re Made Co. headquarters and waits for the reviews to roll in. Realizing that waiting is unnecessary, he writes and posts the reviews himself. One by the Wall Street Journal. Three by The New York Times. Under his direction, Penelope Green writes a feature, with a quote by Ms. Antonelli. "Tools, especially beautifully crafted ones, are irresistible, and it is not only a guys' thing. If hardware store catalogs are already enough to make us swoon, imagine a collection of perfectly crafted plungers. They shoot an electric shock smack into the archipallium."

Smith-Buchanan says, "With the plunger, I wanted to do something simple and sweet." and Ms. Green quotes him. He posts the review on Re Made and shares it on social media.

On Facebook, Best Made posts a decapitated pig's head clenching an axe in its teeth. "smoked pig Best Made style." Best Made followers comment. "Sweet .... I'm making one Wednesday." "tasty." "disgusting." "The only thing disgusting about this picture is that the contents of it aren't near my face."

Re Made posts "smoked pig Re Made style" on Facebook with uncanny accuracy: the BBQ pig head gnawing on a plunger helve rests on a platter, sentimentally laid out on a red-and-whitecheckered tablecloth. Re Made followers comment. "Wtf." "Really gross." "Don't want to see that again, please."

Best Made posts a photo of an axe being clutched by strong hands beneath a commanding mustache and beard. "Merry Axe-Mas ya'll! We invite everyone in NYC to come down to the last axe restoration of 2012, where Nick Zdon will unfurl the greatest holiday miracle of them all as he transforms rusted old choppers into shiny, sparkling blades of wonder \& joy. That's 
happening at 4pm at our shop at 36 White Street in Tribeca. Oh- and there will be whiskey served."

Re Made posts "We invite everyone in NYC to come down to the last plunger restoration, where we'll transform crusted old turd wrenches into shiny, sparkling bowls of wonder \& joy. That's happening at 4pm at our shop at 36 Black Street in Tribeca. Oh- and there will be whiskey served."

Smith-Buchanan arranges, constructs, poses, and snaps three hundred more versions of Best Made posts, politely replacing "axe" with "plunger" so as not to step directly on the BuchananSmith shadow. The Black Keys-inspired polka dot plunger. The sausage-making workshop. Step-by-step guide to Buffing your Plunger. The international plunger archive. Plungers ("bombshells") waiting to be shipped to an L.A. gallery. Peter sizing up his mark in the Catskills. Who wants a plunger sling? Shawn plunging his first bowl. Some pocket plungers used to prototype new handle designs. The Red Cap of Courage. Snow leopard tracks outside the St. Paul outpost. A beautiful Japanese plumber's plunger hangs peacefully in a New York City apartment. Happiness is coming home to a Re Made plunger! Some shots of Woody Welch getting down to business at our plunger restoration workshop in Texas.

Soon, word of the fine-crafted plungers begins to spread online and Smith-Buchanan finds that he can stop writing his own reviews.

Why? Because traditional. Because artisanal. Because dependable.

I purchased a Re Made plunger and I can tell you that it was more than a simple transaction. I feel like it was an investment into a substantial, lasting product and relationship between me and my plunger, between me and those I spend time with around the toilet, and between me and Re Made. I hope to one day hand my Re Made plunger down to my sons in a kind of right-of-passage, so to speak. Thank you Re Made Company! You enabled a bold and brave outlook that changes my whole perspective on bathroom courage.

- Jim Chandler, actual man.

A Re Made plunger is a tool for survival and productivity and at its heart it's a symbol of many admirable virtues. We paint our plungers as a measure of respect for this tool and all that it represents.

- Design You Trust

Dependable, versatile and with a rich and powerful history, the American Master Plunger is the quintessential aquatic tool and an icon of American design and ingenuity. Every feature of this plunger was meticulously designed by Re Made in New York. The Dayton pattern head is made from fine silicone American rubber and is hand cast in North Carolina by fourth-generation plunger makers. Buy Now (\$300)

- Gadget Ground

Any man, woman or child that's ever clogged a toilet will truly appreciate the craftsmanship in the American Master Plunger from Re Made Company. If you are into a rugged lifestyle and value true craftsmanship then chances are you already own an American Felling Axe. That's great for those tough outdoor jobs but for those unpleasant indoor tasks like fixing a clogged toilet you need an American Master Plunger. Handmade in New York City. 


\section{- Big Geek Dad}

Eight months in and the American Master Plunger is sharing happiness with the world. The shopping site Touch of Modern asks to sell Re Made plungers to clients who "have so much money, they don't know what to do with it." Heedlessly, they accept brand images of Re Made men poised to attack a side of beef with an American Master Plunger. They post sales of Winsome Whim, Flashman, Paler Male, Hot Hold, and Radiant Beauty at the special price of $\$ 289.99$.

Colleagues in Brazil send word describing new methods for tapping latex. Smith-Buchanan packs his bags and heads to São Paulo, according to Susi Kippenwaller, who is not a dependable source of information.

From: Peter Buchanan-Smith

To: $\quad$ Peter Smith-Buchanan contact@remadeco.org

March 27, 2014, 5:52 PM

COMPOSE

Inbox (308)

Starred

Important

Sent Mail

Drafts (4) a note from Best Made Co.

\author{
Peter Buchanan-Smith \\ to contact * \\ Dear Folks at Remade,
}

\begin{abstract}
More and more I'm finding that what you're up to is undoubtedly causing confusion in the market. Perhaps this your intention? I don't know. My IP lawyer thinks that what you're doing is a serious matter of copyright infringement, and for some time she has insisted that I take legal action. I have asked her to sit tight, and reassured her that we can resolve this without her.
\end{abstract}

Most of your content (minus a few name changes here and there) is taken verbatim - from us. That confuses people: they don't see what you do as parody or satire. The copy that you've thus far published in your existing videos, website, social media, etc was written by us, it is the result of our hard work, it's our original creation, and most of all it's not yours to do with what you want.

I would appreciate an immediate response, and I hope for a quick / painless resolution to this.

Thanks,

Peter

Founder / CEO

bestmadeco.com

From: Susanne Kippenwaller contact@remadeco.org

To: $\quad$ Peter Buchanan-Smith 
coMPose

Inbox (606)

Starred

Important

Sent Mail

Drafts

Circles
Re: a note from Best Made Co.

\author{
Dear Peter,
}

Thanks so much for your message.

Peter's in Brazil this week tapping latex. He returns mid-week next week and l'll make sure he gets your email as soon as he's back in the studio.

best,

Susi

Re Made Co. Intern

From: Jennifer Silverman

To: $\quad$ Peter Smith-Buchanan contact@remadeco.org

Timothy Lynch

Rebekah Modrak rmodrak@umich.edu

April 3, 2014 5:27 PM

Attached please find a letter regarding The Best Made Company.

Very truly yours,

Jennifer D. Silverman

Jennifer D. Silverman, Esq.

Ellenoff Grossman \& Schole LLP

1345 Avenue of the Americas*

New York, NY 10105

Dear Mr. Lynch and Ms. Modrak:

We are intellectual property counsel to the Best Made Company ("Best Made"), a leading outdoor goods company that designs, manufactures, and sells a variety of goods including, but not limited to, axes, apparel, knives, camp supplies, and bags and cases. Best Made operates a website at www.bestmadeco.com (the "Best Made Website") at which it advertises and sells its axes and other products. Best Made advertises its goods on websites including Facebook: https://www.facebook.com/BestMadeCo (the "Best Made Facebook Page").

Our client became aware of a website for a fictitious company called Re Made Company ("Re Made" or "Re Made Company") accessible from the domain name www.remadeco.org which contains content extensively and unlawfully copied from the Best Made Website and the Best Made Facebook Page ("Re Made Website”).

The creator of the Re Made Website has, until recently, concealed his or her identity by registering the domain name for the Re Made Website anonymously. On March 27, 2014, our client 
sent an e-mail to contact@ remadeco.org, an email address appearing on the Re Made Website, requesting that the wholesale copying of the Best Made Website stop. He received a disingenuous response which ignored his demand and referred to "Peter Smith-Buchanan," a name based upon the name of the founder of Best Made Company, Peter Buchanan-Smith. A copy of the email exchange is attached to this letter.

Our investigation into this matter uncovered the Tumblr.com page for the University of Michigan, School of Art \& Design which indicates that the Re Made Website was created by Ms. Rebekah Modrak, an Associate Professor at the University of Michigan School of Art \& Design (as indicated by the black arrow below).

It appears that either Ms. Modrak or others at the University of Michigan may have been involved in creating and operating the Re Made Website and the infringing content that appears on it. Because Ms. Modrak is employed by the University of Michigan, we are writing both to her directly and the University.

The Re Made Website violates our client's intellectual property rights in several ways. First, the Re Made Website mimics the appearance of the Best Made Website in its overall design and in the coordination and arrangement of graphic elements. As an example, below is a screenshot of the homepage for the Best Made Website.

As you can see, the visual elements are virtually identical, and Re Made has essentially copied the product descriptions, mainly changing where necessary to refer to a plunger instead of an axe.

The creator of the Re Made Website has even gone so far as to show on its "About Us" section fake New York Times and Wall Street Journal articles. The relevant pages from the site appear below, and it is apparent that the articles are fake because when a visitor clicks on one of their URL links, the visitor is re-directed to a webpage at a domain name that begins with "remadeco.org", and does not re-direct to either the New York Times or Wall Street Journal websites as does the article about Best Made. And as far as we can find, no such articles about Re Made Company appear on the websites for the New York Times or Wall Street Journal.

As you can see from the examples above, the creator of the Re Made Website has blatantly copied wholesale textual and graphical content from the Best Made Website. In addition to that, the most egregious example of co-opting Best Made's content is Re Made's video about its "Re Made American Master Plunger" which appears on the Re Made Website. A screenshot of the webpage showing the video appears below, and the video can be viewed at the following URL link.

It is clear that the Re Made video was directly copied from the original Best Made video. In fact, the Re Made video not only identically mimics the sequence and images of the Best Made Video, but also copies, virtually verbatim, the almost three-and-a-half minutes of narrative dialogue spoken by Best Made's founder Peter Buchanan-Smith. However, in the Re Made video it is "Peter Smith Buchanan" doing the speaking on behalf of Re Made Company, and the only main difference between the two is that the Re Made video refers to a plunger instead of an axe.

Best Made is the owner of all rights, title, and interests in and to the Best Made Website, the Best Made video and other content that appears on the Best Made Website and Facebook Page, including any and all copyrights that may exist in the same. The creation and publication of the Re Made Website, and the infringing content that appears on it, constitutes copyright 
infringement under the United States Copyright Act, 17 U.S.C. $\$ 101$ et seq. Such wrongdoing may entitle Best Made to an injunction, an award of damages, disgorgement of profits, and/or an award of costs and attorneys' fees. In addition, if such infringement is found to be intentional, willful, or malicious, any damages award may be trebled.

Re Made Company has not only slavishly copied the overall appearance of the Best Made Website, but has also co-opted the overall look and appearance of Best Made's various axes appearing on the Best Made Website with different colored handles.

Our client realizes that, to some extent, the actions of Ms. Modrak or any others at the University of Michigan School of Art \& Design who may have been involved may have been taken in an effort to parody, satire, or "poke fun" at Best Made and its founder Peter BuchananSmith, or to make some other kind of "artistic statement." However, in our view, the perpetrator(s) may not avail themselves of a fair use "parody" defense due to the sheer volume of material copied from the Best Made Website and Best Made video. The creator(s) of the Re Made Website have extensively copied wholesale several aspects and elements of the Best Made Website from its overall appearance down to very minute details such as the product descriptions and other textual content that appears on the Best Made Website, even going so far as not changing the "Best Made" name, email address, and phone number in the "Help" section and creating false New York Times and Wall Street Journal articles. They have also meticulously copied the sequence and narrative of the Best Made video. It would be possible to make a parody or satirical, humorous, or artistic statement without resorting to such wholesale copying. There is nothing, in fact, on the Re Made Website even indicating it is a parody or joke or that it is the site of a fictitious company, but rather gives the impression that Re Made Company is an actual company.

The first question Jennifer Silverman, lawyer for Best Made Co., asks Rebekah Modrak via her University of Michigan attorney is "Do you know Peter Buchanan-Smith?." Rebekah understands why the question is being asked. She knows that the owner of the upscale axe company is behind the question, and knows why he's asking. The Yes Men are serious artists even while wearing a gold lamé suit with a colossal, inflated phallus, and no one ever accuses the canary of being lovesick from lack of oxygen, but there's jilted amour at the core of every woman. It's a question that should never have been asked so Rebekah feigns incomprehension.

It is now Buchanan-Smith's opportunity to tell the story of Re Made and the story of Rebekah Modrak. Rebekah Modrak is no professor, no cultural critic, no interventionist artist. Rebekah Modrak perceived of the need for revenge. Revenge via plunger company. Revenge on the boy who broke her heart in the third grade when he stopped playing footsies timed to Mrs. McNellis' glances. All these years, Rebekah kept tabs on Buchanan-Smith. Hiding behind trees, watching him cook the wagyu. Planning the details of the plunger company in her head.

On the final day of negotiations between axe lawyers and plunger lawyers, the university attorney for the plungers asks senior axe attorney Jennifer Silverman to close her eyes. "Imagine," he says, "the cartoon on page 29 of the New Yorker's July $11^{\text {th }}$ edition. A 
lumbersexual waving an axe is chasing a lumbersexual with a plunger down the streets of Williamsburg. Imagine the uproar over art censorship." The negotiations end. Not with a whack and a flourish, but with a flush and a trickle as the axe attorneys disappear, like you might imagine with fairies, or a tornado.

Rebekah perceives of the need for a better cease and desist. The plaintiffs will be laborers. First, Teal describes the constant pain he endures from nerve damage caused by working with manual tools all his life. He asks to include a photo of his swollen knuckles. "My hands have been my livelihood for 30 years, since I was old enough to push a lawnmower at 7 . I'm only 53. I feel like I'm 73 from my waist up or back down. I always did the work myself. Three years ago, I excavated a basement and waterproofed it. I hauled in 12 yards of dirt and backfilled. That was all done by hand with shovels and compacters. I hand-bricked the whole thing because I couldn't afford $\$ 1100$ to rent the machine. That was $\$ 1100$ I could use for food or gas. And now I'm paying for it. I retired from construction about a year and a half ago. I'm now a farmer because, at a point where I can't move, at least I can crawl and I still get along the row of the gardens. And when someone comes by, I can just raise a hand to help me up."

"I won't even eat dinner sometimes after work," Chris writes. "I will just fall asleep. Physically taxing, emotionally taxing. I wish I could be working less hours. A lot of times the construction work is for pretty cottages and stuff for affluent summer people. I like to have tangible things left over from my work and, yeah, there's a house, but it's not for me. The work isn't for me. It's for these people who have everything. So that can wear on you sometimes."

John works outside even in winters. He wears thin gloves so he can still handle nails. "My hands are horrible right now in the cold. This winter was really hard. Thank God I got through it, but every year I keep saying I'm going to find inside work and then I never do. Back when I was younger I loved it because l'd just run all day and then feel good at the end of the day having built walls and everything. Then about eight years later my body starts hurting. I start getting tired and so then it was just about survival after that. But then I could never make the transition into anything else. I've heard of a guy that broke his leg right here, a wall fell on him. There was a really good carpenter in Union Lake, and he was probably 60 years old. He was really a master framer and they were carrying walls, smaller walls with sheeting on them, and moving them around because sometimes you'll build them somewhere and you get the sheeting on it and then you'll carry them and lift them and make them into panels. And they walked over a stairwell hole and didn't see. They were carrying a wall and he fell two or three stories down a stairwell hole and died."

Re Made's attorney Jennifer Mansilver edits the workers' cease and desist before sending it to the axe lawyers. "Most of your content is taken from us," she notes. "That confuses people; they don't see what you do as marketing or rhetoric. The copy that you've thus published in your existing videos, website, social media, etc., was built off of our backs, it is the result of our hard work, it's our original creation, and most of all it's not yours to do with what you want." 


\section{AUTHOR BIO}

Rebekah Modrak critiques and challenges consumer culture through creative work utilizing interventionist methods and published writing across digital space. She is currently a Professor in the Stamps School of Art \& Design at the University of Michigan. 